\title{
THE GLOBAL EPIDEMIOLOGY OF VITAMIN D STATUS
}

\author{
M.H. Edwards ${ }^{1,4}$, Z.A. Cole ${ }^{1,4}$, N.C. Harvey ${ }^{1}$, C. Cooper ${ }^{1,2,3}$
}

\begin{abstract}
Objective: Vitamin D is an important component of calcium and phosphate metabolism, ensuring, with PTH and FGF23, adequate serum concentrations of these two analytes for optimal cell function and bone mineralisation. Despite a surge of interest in vitamin D physiology over the last decade, a single threshold for deficiency remains uncertain in functional terms, and it is clear that correlation between serum concentration of $25(\mathrm{OH})$-vitamin $\mathrm{D}$ and disease outcomes is very poor at the level of the individual. In this review, we describe the physiology of vitamin D, its potential associations with disease, and relate, in detail, the epidemiology of vitamin D status across populations worldwide. Design: Through a comprehensive literature review, we identified relevant studies from Europe, the Middle East, Africa, Asia, North America, Latin America, and Oceania. Results: Although rickets and osteomalacia are established potential consequences of vitamin D deficiency, evidence for low levels of vitamin D as a cause of the multitude of other health outcomes with which they have been linked is lacking. We observed geographical differences in serum 25(OH)-vitamin D concentrations, which may be partly, but not wholly, explained by factors such as sunlight exposure, skin pigmentation, skin coverage, dietary choices, supplements, adiposity, malabsorption, disease, demographics and lifestyle. Conclusion: We conclude that low serum concentrations of $25(\mathrm{OH})$-vitamin D appear common across the globe; the relevance of this observation to human health remains to be elucidated.
\end{abstract}

Key words: Vitamin D, epidemiology, global, physiology.

\section{Introduction}

Vitamin D is a fat soluble vitamin involved in bone mineralization.. It is unique in that it can not only be ingested in the diet as cholecalciferol (vitamin D3) or ergocalciferol (vitamin D2) but can also be synthesized in the skin when sunlight exposure is adequate. Despite dual mechanisms of attainment, vitamin D deficiency is not uncommon in many countries throughout the world and can lead to disease. The geographical variation in vitamin D is significant. Particular areas at risk include South Asia and the Middle East. Several factors can affect vitamin D levels on a population and individual basis. Of particular importance are sunlight exposure and modulators of this, such as clothing, sunscreen usage, institutionalization, and latitude. Dietary, lifestyle, and demographic aspects also play a role; specifically, more obese individuals tend to have lower

1. MRC Lifecourse Epidemiology Unit, (University of Southampton), Southampton General Hospital, Southampton, SO16 6YD, UK; 2. Biomedical Research Unit, University Hospital Southampton NHS Foundation Trust, Southampton SO16 6YD, UK; 3. Institute of Musculoskeletal Sciences, University of Oxford, Oxford OX3 7LD, UK; 4. ME and ZAC are joint first authors.

Corresponding Author: Professor Cyrus Cooper, MRC Lifecourse Epidemiology Unit, (University of Southampton), Southampton General Hospital, Southampton, SO16 6YD, UK. Tel: +44 (0)23 80777624 Fax: +44 (0)23 80704021 Email: cc@mrc.soton.ac.uk

Received September 24, 2013

Accepted for publication January 29, 2014 vitamin D levels. This review describes the importance of vitamin $\mathrm{D}$ for bone and muscle health and highlights the uncertainties regarding effects on nonmusculoskeletal outcomes. It also explores the possible determinants of the geographical variation in vitamin $\mathrm{D}$ status which might inform the development and implementation of targeted interventions and future public health policies.

\section{The importance of Vitamin D}

Vitamin D has many functions in humans including calcium and phosphate homeostasis. Once absorbed from the gut or produced in the skin, it is then hydroxylated in the liver into 25-hydroxyvitamin D $(25(\mathrm{OH}) \mathrm{D})$ and then in the kidney and in extrarenal tissues to 1,25-dihydroxyvitamin D $(1,25(\mathrm{OH}) 2 \mathrm{D})$ and 24,25 -dihydroxyvitamin D $(24,25(\mathrm{OH}) 2 \mathrm{D})$. Thereafter, the active metabolite can enter cells and bind to either the vitamin D-receptor or to a responsive gene, such as that of calcium binding protein, and thus assist in calcium absorption (1). Vitamin D also regulates parathyroid hormone (PTH) levels which in turn reduces bone loss (2). Severe vitamin D deficiency causes new bone, the osteoid, not to be mineralized. This can lead to rickets in 
children and osteomalacia in adults.

Vitamin D deficiency has been associated with lower BMD in individuals without frank osteomalacia $(3,4)$; however a recent meta-analysis showed only a small effect of vitamin D supplementation on femoral neck BMD and no significant effect at other sites (5). This is consistent with studies of vitamin $\mathrm{D}$ and fracture which have shown that although there two are associated (6), intervention trials tend to fail to show a benefit of supplementation $(7,8)$.

Vitamin D acts on muscles through genomic and nongenomic pathways. The genomic pathway involves activation of the $1,25(\mathrm{OH}) 2 \mathrm{D}$ nuclear receptors resulting in messenger RNA production and the synthesis of various proteins $(9,10)$. The non-genomic pathway acts through a secondary messenger in the cell or by activating protein kinase $C(11,12)$. It is not surprising therefore that in cases of severe vitamin $D$ deficiency causing rickets or osteomalacia, a myopathy can develop(13-15). When severe, it presents with marked proximal muscle weakness with a predilection for the lower limbs (13).

In contrast, observational studies at the population level have failed to show consistent associations between vitamin D and muscle strength. Although some studies have shown crude associations with leg strength $(16,17)$ and grip strength (18), these relationships are completely attenuated after adjustment for potential covariates. Furthermore, studies investigating the effects of vitamin D supplementation on muscle function have also found inconsistent results (15).

Recently vitamin D has also been linked with several other conditions. Associations have been shown with colorectal cancer (19), diabetes mellitus (20), infection (21), multiple sclerosis, cardiovascular disease, breast cancer, autoimmunity and allergy (22), depression (23), and postural instability (24). These relationships are found mainly in observational studies which are open to many interpretations. For example, there is the possibility of confounding through several associated factors, such as physical activity, and reverse causality, when the disease may lead to a greater time spent indoors resulting in reduced sunlight exposure. Furthermore, there is evidence that vitamin D levels decrease during an inflammatory response which might partly explain associations with inflammatory conditions $(25,26)$. Publication bias is also a significant issue as there is a reluctance to publish negative findings which leads to a predominance of positive associations in the literature. It is therefore important to exercise caution when examining the evidence of such relationships. However, the absence of large randomised controlled trial evidence in these areas by no means excludes such causative relationships. Furthermore, bearing these provisos in mind, recently systematic reviews have been carried out assessing multiple potential outcomes. Amongst their findings is emerging evidence of a direct role for vitamin $\mathrm{D}$ in regulation of immune function, both innate and adaptive $(27,28)$.

The assessment of Vitamin D status is also a contentious issue. It is usually best measured by assessment of serum $25(\mathrm{OH}) \mathrm{D}(29,30)$, however, there is disagreement about what level constitutes deficiency. Although levels below $25 \mathrm{nmol} / 1$ have been associated with bone metabolic disorders (31), using post-mortem specimens, a recent study found that a large proportion of those individuals with serum levels below $25 \mathrm{nmol} / 1$ did not have abnormal bone histology and several with higher levels did (32). Other studies have assessed relationships between $25(\mathrm{OH}) \mathrm{D}$ and parathyroid hormone (PTH) levels in relation to bone health, however, it was found that the $25(\mathrm{OH}) \mathrm{D}$ level at which PTH reached a plateau varied considerably between 25 $\mathrm{nmol} / 1$ and $125 \mathrm{nmol} / \mathrm{l}$ (33). At present, it is therefore not possible to accurately determine an individual's bone health based on a vitamin D level alone and thus debate on the threshold for deficiency continues. The lack of consensus on a definition of vitamin D deficiency has significantly affected the prevalence rates reported by various studies in different geographical locations. It is important that this is taken into consideration when reviewing the findings of such studies.

\section{Factors affecting Vitamin D levels}

When assessing factors that affect Vitamin D levels, it is logical to start with those that influence acquisition; namely skin synthesis and dietary intake. The effectiveness of vitamin D production in the skin is dependent on the intensity of sunlight to which it is exposed. Consequently, in winter vitamin D synthesis may slow and, in some cooler climates, even cease completely. Intuitively, it would be expected that vitamin $\mathrm{D}$ levels would be higher closer to the equator where sunlight intensity is greater. However, some studies have shown the contrary, with levels higher in northern than southern Europe $(34,31)$. This can partly be explained by skin pigmentation. Populations in warmer climates tend to have greater skin pigmentation which can affect their ability to synthesis vitamin D. Migration can therefore have a significant impact. White women living in the south of England had median 25(OH)D levels of $62.5 \mathrm{nmol} / 1$ in the summer and 39.9 $\mathrm{nmol} / \mathrm{l}$ in the winter. In Asian women living in the same geographical location the median levels were considerably less at $24.9 \mathrm{nmol} / 1$ and $16.9 \mathrm{nmol} / 1$ respectively (35). Furthermore, synthesis only occurs if adequate skin is exposed. In some countries cultural factors influence style of dress with effects on skin vitamin $\mathrm{D}$ conversion $(36,37)$. It has also been shown that the application of sunscreen has a similar effect (38, 39), although a study from Australia found that regular 
usage did not cause vitamin D levels to fall outside the normal reference range (40).

Vitamin D is additionally obtained from the diet although the contribution to total levels tends to be small in comparison to skin synthesis. It can be ingested as ergocalciferol (vitamin D2) or cholecalciferol (vitamin D3). Ergocalciferol is obtained from plant sources such as mushrooms, whereas cholecalciferol is contained mainly in oily fish and egg yolk. Several supplements are also available although due to a lack of stringent regulation, there may be discrepancies between the label value and the true levels contained within the formulation (41). Cod liver oil contains high levels of Vitamin D and as is taken commonly in Scandinavia. This can partly explain the higher serum levels found in northern Europe (42). In many regions, including Canada and America (43), fortification of foods, including milk and cereals, with vitamin $D$ is routine. There is however significant geographic variation and in some countries, particularly in the developing world, it does not occur at all. This may have significant effects on overall population levels.

Diet is also important in the maintenance of a healthy weight. Obesity is becoming more prevalent and has effects on vitamin $\mathrm{D}$ bioavailability. Overall obese people have a lower $25(\mathrm{OH}) \mathrm{D}$ level than those of normal weight $(44,45)$. Vitamin D is a fat-soluble vitamin and as such it can move into adipose tissue (46) which can lead to a drop in serum levels. This has also been associated with increased parathyroid hormone levels (47).

Vitamin D levels have a significant hereditable component suggesting a possible role for genetics in the etiology of insufficiency. Results from a genome-wide association study have confirmed that variants near genes involved in dihydrocholesterol metabolism, cholesterol synthesis, hydroxylation, and vitamin D transport can affect vitamin D status (48).

Demographic factors have also long been a source of interest in the epidemiology of vitamin D deficiency. Several reviews have shown significant differences in vitamin D levels with age $(34,49,50)$. In the Middle East and Africa, children tend to have higher vitamin D levels than adults (51). This may reflect the greater amount of time they spend outside compared to other age groups. Recently, however, it has been shown that these differences are reducing which may be the result of a change in lifestyle in developed countries, with younger people spending a greater amount of time indoors (e.g. watching television and playing computer games) (52). The very elderly population has been found to be a group a particular risk of vitamin D deficiency. This is in part due to them producing less cholecalciferol with the same exposure to UVB light as younger adults but also to less time spent outside (53). The latter is particularly true of those institutionalized elderly $(34,42)$.

Women have often been found to have lower levels of $25(\mathrm{OH}) \mathrm{D}$ levels than men $(42,49,50)$. Potential causes include differences in body fat composition, resulting in greater fat storage of vitamin D in women. Lower levels in women are a particular concern around the time of childbearing as the vitamin D status of a women during pregnancy is an important factor in the determination of the vitamin D status in her child (54).

At the population level the above factors can have significant effects on rates of vitamin D deficiency. For example, populations with greater numbers of older people will have an increased risk. At the individual level, genetic factors will also play a role. Many diseases reduce vitamin $\mathrm{D}$ levels, mainly by affecting absorption and metabolism. Malabsorption can be a primary intestinal syndrome, such as coeliac disease, Crohn's disease, Whipple's disease, or short bowel syndrome. Fat malabsorption is also problematic as vitamin $\mathrm{D}$ is a fat soluble vitamin. Hepatic and renal disease are well known to disrupt vitamin D metabolism and several drugs and inherited disorders have also been implicated. Independently, however, these conditions are relatively rare and are not known to have significant effects on the epidemiology of vitamin D deficiency at the population level.

In summary, vitamin D status is largely determined by the level of skin synthesis and dietary intake. Vitamin D synthesized in the skin is dependent on UVB exposure and therefore influenced by latitude, skin pigmentation, skin coverage, time spent outdoors, and use of sunscreen. Dietary vitamin D can be obtained throughs naturally occurring ergocalciferol or cholecalciferol in foodstuffs, dietary supplementation, or food fortification. A number of other factors such as adiposity, genetics, age, sex, and specific diseases also contribute to variation.

\section{Geographical Variation in Vitamin D Levels}

Vitamin D status has been assessed in numerous studies worldwide (table 1). However, data from Africa and Latin America are currently scarce. It should be noted that studies are not always directly comparable, since there are several different assays and interlaboratory variation is still considerable. For the purposes of this review the threshold has been set at a serum level of 50nmol/1 25(OH)D and Vitamin D deficiency is described as a $25(\mathrm{OH}) \mathrm{D}$ level of less than $25 \mathrm{nmol} / 1$ unless otherwise stated as these are the most commonly used definitions. In 2010 the Institute of Medicine report considered data from two large systematic reviews to access the relationship between vitamin D, PTH and calcium absorption. They developed a schematic representation of the relationship between vitamin $\mathrm{D}$ status as measured by serum $25 \mathrm{OHD}$ and integrated bone health outcomes and suggested that a serum 25OHD of $40 \mathrm{nmol} / \mathrm{L}$ is sufficient to meet the vitamin $\mathrm{D}$ requirement for bone health in half the population, while $50 \mathrm{nmol} / \mathrm{L}$ would be sufficient for $97.5 \%$ of the population. They 
Table 1

Studies describing vitamin D levels and participant demographics

\begin{tabular}{|c|c|c|c|c|c|c|}
\hline & Country & Age (years) & Sex & $\begin{array}{c}\text { Number of } \\
\text { Participants }\end{array}$ & $\begin{array}{c}\text { Mean 25(OH) } \\
\text { Vitamin D }\end{array}$ & $\begin{array}{l}\text { Additional } \\
\text { information }\end{array}$ \\
\hline \multicolumn{7}{|l|}{ Europe } \\
\hline Melhus (58) & Sweden & 71 & M & 1194 & 68.7 & \\
\hline Chapuy (59) & France & $35-65$ & $\mathrm{M}+\mathrm{F}$ & 1569 & 61 & \\
\hline Semba (60) & Italy & $65+$ & $\mathrm{M}+\mathrm{F}$ & 1006 & 39.9 & \\
\hline Burnand (61) & Switzerland & $25-74$ & $\mathrm{M}+\mathrm{F}$ & 3276 & 50 & \\
\hline Pilz (62) & Austria & $70+$ & F & 961 & 17.5 & \\
\hline Krieg (63) & Switzerland & $70+$ & $\mathrm{M}+\mathrm{F}$ & 367 & $\begin{array}{l}23.2 \\
25.5\end{array}$ & $\begin{array}{l}\text { Female } \\
\text { Male }\end{array}$ \\
\hline Tolppanen (64) & UK & 9.9 & $\mathrm{M}+\mathrm{F}$ & 7565 & 60.7 & \\
\hline Das (66) & UK & $14.7-16.6$ & $\mathrm{~F}$ & 37 & $\begin{array}{l}14.8 \\
37.3\end{array}$ & $\begin{array}{l}\text { Non-white } \\
\text { White }\end{array}$ \\
\hline Serhan (67) & UK & $18+$ & $\mathrm{M}+\mathrm{F}$ asian & 98 & 16.5 & \\
\hline Van der Meer (68) & Netherlands & $18-65$ & $\mathrm{M}+\mathrm{F}$ & 613 & $\begin{array}{l}27^{*} \\
30^{*} \\
38^{*}\end{array}$ & $\begin{array}{c}\text { Turkish } \\
\text { Moroccan } \\
\text { Other non Western }\end{array}$ \\
\hline Van der Meer (69) & Netherlands & child bearing age & F pregnant & 358 & $\begin{array}{l}15.2^{*} \\
20.1 \\
26.3 \\
52.7\end{array}$ & $\begin{array}{c}\text { Turkish } \\
\text { Moroccan } \\
\text { Other non Western } \\
\text { Western }\end{array}$ \\
\hline \multicolumn{7}{|l|}{ Middle East/Africa } \\
\hline Alagol (71) & Turkey & $14-44$ & $\mathrm{~F}$ & 48 & $\begin{array}{c}56 \\
31.9 \\
\text { uncovered } \\
9\end{array}$ & $\begin{array}{l}\text { Non-veiled } \\
\text { Hands/face } \\
\text { Fully veiled }\end{array}$ \\
\hline Ardawi (72) & Saudi Arabia & $20-74$ & M & 834 & 29 & \\
\hline Ardawi (73) & Saudi Arabia & $20-79$ & $\mathrm{~F}$ & 1172 & 35.8 & \\
\hline Andiran (74) & Turkey & $0-16$ & $\mathrm{M}+\mathrm{F}$ & 440 & $\begin{array}{c}85 \\
51.2 \\
46.7\end{array}$ & $\begin{array}{l}0-5 \text { years } \\
5-10 \text { years } \\
10-16 \text { years }\end{array}$ \\
\hline Mansour (75) & Saudi Arabia & $4-15$ & $\mathrm{M}+\mathrm{F}$ & 510 & 32.6 & \\
\hline Aspray (76) & Gambia & $25+$ & $\mathrm{F}$ & 112 & 91.3 & \\
\hline Njemini (77) & Cameroon & $60+$ & $\mathrm{M}+\mathrm{F}$ & 152 & 52.7 & \\
\hline Luxwolda (78) & Tanzania & $>16$ & $\mathrm{M}+\mathrm{F}$ & $\begin{array}{c}88 \\
139\end{array}$ & $\begin{array}{l}106.8 \\
138.5\end{array}$ & $\begin{array}{c}\text { Non-pregnant } \\
\text { Pregnant }\end{array}$ \\
\hline Allali (79) & Morocco & $24-77$ & $\mathrm{~F}$ & 415 & 42.4 & \\
\hline Meddeb (80) & Tunisia & $20-60$ & $\mathrm{~F}$ & 261 & 40.3 & \\
\hline \multicolumn{7}{|l|}{ Asia } \\
\hline Arya (81) & India & $16-65$ & $\mathrm{M}+\mathrm{F}$ & 92 & 30 & \\
\hline Marwaha (82) & India & $>16$ & $\mathrm{~F}$ & 541 & 23.2 & Pregnant \\
\hline Puri (83) & India & $6-18$ & $\mathrm{~F}$ & 3127 & 31.9 & \\
\hline Sachan (84) & Northern India & $>16$ & F & 207 & 34.9 & Pregnant \\
\hline Harinarayan (85) & India & $<18$ & $\mathrm{M}+\mathrm{F}$ & 117 & 21 & \\
\hline Agarwal (86) & India & 9-24 months & $\mathrm{M}+\mathrm{F}$ & 34 & $\begin{array}{l}30.9 \\
67.6\end{array}$ & $\begin{array}{l}\text { High pollution } \\
\text { Low pollution }\end{array}$ \\
\hline \multirow[t]{2}{*}{ Islam (87) } & Bangledesh & $16-40$ & F & 189 & 36.7 & $\begin{array}{l}\text { Low socio- } \\
\text { economic class }\end{array}$ \\
\hline & & & & & 43.5 & $\begin{array}{l}\text { High socio- } \\
\text { economic class }\end{array}$ \\
\hline \multirow[t]{4}{*}{ Atiq (89) } & Pakistan & 6-11 months & F adult & 62 & 39.8 & $\begin{array}{l}\text { Lower class } \\
\text { nursing mother }\end{array}$ \\
\hline & & & & & 26.5 & $\begin{array}{l}\text { Higher class } \\
\text { nursing mother }\end{array}$ \\
\hline & & & $\mathrm{M}+\mathrm{F}$ infant & & 52.3 & $\begin{array}{l}\text { Lower class } \\
\text { breastfed infant }\end{array}$ \\
\hline & & & & & 22.5 & $\begin{array}{l}\text { Higher class } \\
\text { breastfed infant }\end{array}$ \\
\hline \multirow[t]{2}{*}{ Ho Pham (90) } & Vietnam & $18-87$ & $\mathrm{M}+\mathrm{F}$ & 637 & 91.8 & Men \\
\hline & & & & & 75.1 & Women \\
\hline Chailurkit (91) & Thailand & $15-98$ & $\mathrm{M}+\mathrm{F}$ & 2641 & $\begin{array}{l}64.8 \\
795\end{array}$ & Bangkok \\
\hline
\end{tabular}




\begin{tabular}{|c|c|c|c|c|c|c|}
\hline Rahman (92) & Malaysia & $50-65$ & F & 101 & $\begin{array}{l}81.7 \\
78.3 \\
44.4 \\
68.8\end{array}$ & $\begin{array}{l}\text { Northern } \\
\text { Southern } \\
\text { Malay } \\
\text { Chinese }\end{array}$ \\
\hline Chen (94) & Central China & $40-69$ & $\mathrm{M}+\mathrm{F}$ & 2018 & 31.7 & \\
\hline Foo (95) & China & 15 & $\mathrm{~F}$ & 301 & 34 & \\
\hline Lander (96) & Mongolia & 6-36 months & $\mathrm{M}+\mathrm{F}$ & 98 & 24.1 & \\
\hline Suzuki (98) & Japan & $65-92$ & $\mathrm{M}+\mathrm{F}$ & 2957 & $\begin{array}{l}60.4 \\
70.1\end{array}$ & $\begin{array}{c}\text { Women } \\
\text { Men }\end{array}$ \\
\hline \multicolumn{7}{|l|}{ North America } \\
\hline Looker (99) & USA & all ages & $\mathrm{M}+\mathrm{F}$ & 20,289 & $\begin{array}{c}76.4 \\
70 \\
63.9 \\
62 \\
59.2 \\
57.5\end{array}$ & $\begin{array}{c}1-5 \text { years } \\
6-11 \text { years } \\
12-19 \text { years } \\
20-49 \text { years } \\
50-60 \text { years } \\
>70 \text { years }\end{array}$ \\
\hline Langlois (100) & Canada & $6-79$ & $\mathrm{M}+\mathrm{F}$ & 5306 & 67.7 & \\
\hline Berger (101) & Canada & $>25$ & $\mathrm{~F}$ & 1896 & $\begin{array}{l}70.7 \\
69.9\end{array}$ & $\begin{array}{l}\text { Women treated for } \\
\text { osteoporosis } \\
\text { Men treated for } \\
\text { osteoporosis }\end{array}$ \\
\hline \multicolumn{7}{|l|}{ South America } \\
\hline Lips (102) & $\begin{array}{c}\text { Mexico } \\
\text { Brazil } \\
\text { Chile }\end{array}$ & $>45$ & $\mathrm{~F}$ & $\begin{array}{l}149 \\
151 \\
115\end{array}$ & $\begin{array}{l}65.4 \\
81.3 \\
75.4\end{array}$ & \\
\hline Oliveri (103) & Argentina & $>65$ & $\mathrm{M}+\mathrm{F}$ & 389 & $\begin{array}{l}35.4 \\
44.7 \\
51.7\end{array}$ & $\begin{array}{l}\text { South } \\
\text { Mid } \\
\text { North }\end{array}$ \\
\hline \multicolumn{6}{|l|}{ Oceania } & \\
\hline Brock (105) & Australia & $>18$ & $\mathrm{M}+\mathrm{F}$ & 377 & $\begin{array}{l}44 \\
36 \\
33\end{array}$ & $\begin{array}{l}\text { Living at home } \\
\text { Living in hostel } \\
\text { Living in nursing } \\
\text { home }\end{array}$ \\
\hline Ding (106) & Tasmania & & $\mathrm{F}$ & 1002 & 52.8 & \\
\hline Rockell (107) & New Zealand & $>15$ & $\mathrm{M}+\mathrm{F}$ & 3008 & 50 & \\
\hline Rockell (108) & New Zealand & $5-14$ & $\mathrm{M}+\mathrm{F}$ & 1585 & 43 & Maori \\
\hline
\end{tabular}

concluded that people are at risk of deficiency when serum $25 \mathrm{OHD}$ is $<30 \mathrm{nmol} / \mathrm{L}$, that some people are potentially at risk of inadequacy when serum 25OHD is $30-50 \mathrm{nmol} / \mathrm{L}$, and that over $50 \mathrm{nmol} / 1$ is sufficient for almost all of the population (55).

\section{Europe}

The region in which the largest number of studies have been conducted is Europe. Within Europe there is high variation in serum $25(\mathrm{OH}) \mathrm{D}$ levels. One of the earliest reviews, the Euronut-Seneca study, compared the vitamin D status of 824 elderly people living in 11 European countries (56). Forty seven percent of the women and $36 \%$ of the men had serum levels $<30 \mathrm{nmol} / 1$ with vitamin $\mathrm{D}$ levels decreasing with age. Vitamin D concentrations were higher in the Northern European and Scandinavian countries compared to Southern Europe (56). As described above, this strong correlation between latitude and serum vitamin $\mathrm{D}$ was unexpected because ultraviolet irradiation is higher in southern Europe. A similar geographical correlation was observed between serum 25(OH)D and latitude in the MORE study which looked at the effect of raloxefene or placebo in osteoporotic women (57). The Uppsala Longitudinal Study of Adult Men in Sweden showed that despite no cutaneous synthesis of vitamin D during the winter months at this latitude only $5 \%$ had serum levels $<40 \mathrm{nmol} / 1$ (58). It is unclear whether this is due to increased dietary intake, such as cod liver oil consumption, or whether there is a genetic adaptation to ultraviolet light in this population. In France, the Suvimax study of 1529 men and women aged 35-65 years, showed a correlation between latitude and serum $25(\mathrm{OH}) \mathrm{D}$, with mean levels lower $(43 \mathrm{nmol} / 1)$ in the north and higher $(94 \mathrm{nmol} / \mathrm{l})$ in the south west (59). An Italian study based in Chianti, Tuscany studied 1006 men and women $>65$ years, $25 \%$ of their participants had a $25(\mathrm{OH}) \mathrm{D}<26 \mathrm{nmol} / 1$. Lower serum 25(OH)D was found in the more elderly, women, non smokers, those who were physically inactive or who had poorer health, and those with a lower level of education (60). A large Swiss study of 3276 men and women aged 25-74 years showed lower serum 25(OH)D levels was again associated with 
older age ( $>65$ years), less than 30 minutes outside daily, winter season and poor vitamin D nutritional intake, represented by absent margarine or butter intake and poor dairy consumption. Median levels in this population were $46 \mathrm{nmol} / 1$ with only $6 \%$ having serum levels $<20 \mathrm{nmol} / 1$ (61).

A number of studies have confirmed that vitamin D deficiency is particularly common in the institutionalized elderly. A recent study in Austria showed that the median 25(OH)D serum level was $17.5(13.7-25.5) \mathrm{nmol} / 1$. Only $6 \%$ of this population had a level $>50 \mathrm{nmol} / 1$ (62). Higher levels of mortality were associated with lower serum levels. This similarly compares to a Swiss study of 19 nursing homes in which $41.9 \%$ of the women and $31.4 \%$ of the men had a serum $25(\mathrm{OH}) \mathrm{D}$ level below $15.5 \mathrm{nmol} / 1$ compared to $2.5 \%$ of the controls (63).

Vitamin D insufficiency is common amongst children. The ALSPAC birth cohort in the UK assessed 7560 children aged 9.9 years. $1.6 \%$ had serum $25(\mathrm{OH}) \mathrm{D}$ levels $<25 \mathrm{nmol} / 1,29 \%$ had levels $<45 \mathrm{nmol} / 1$ and $75 \%$ had serum levels $<75 \mathrm{nmol} / 1(64)$. Less time spent outdoors, lower socioeconomic status, more advanced pubertal stage, non-white ethnicity and female gender were all associated with vitamin D deficiency (64). Similar results were seen in children referred to an orthopaedic clinic in Southampton, UK. 32\% had vitamin D insufficiency with $25(\mathrm{OH}) \mathrm{D}$ levels $<50 \mathrm{nmol} / \mathrm{L}$ and $8 \%$ had vitamin $\mathrm{D}$ deficiency (25(OH)D $<25 \mathrm{nmol} / \mathrm{l})(65)$.

As expected, immigrants from Asian countries have a much higher risk for severe vitamin D deficiency. Serum 25(OH)D levels from a small healthy cohort of non-white, mainly south Asian girls in Manchester UK showed a mean serum $25(\mathrm{OH}) \mathrm{D}$ of $14.8 \mathrm{nmol} / 1$ indicating severe vitamin D deficiency. $73 \%$ of the girls studied had levels $<30 \mathrm{nmol} / 1$ (66). Among the Indo-Asian population attending a rheumatology clinic in Wolverhampton UK, $78 \%$ had a $25(\mathrm{OH}) \mathrm{D}$ level $<20 \mathrm{nmol} / \mathrm{l}$, compared to $58 \%$ of the control population (67). A study from the Netherlands looked at 613 adults over 18 years in general practice (68). The prevalence of vitamin D deficiency was higher in Turkish (41.3\%), Moroccan (36.5\%), Surinam South Asian (51.4\%), Surinam Creole (45.3\%), subSaharan African (19.3\%) and other adults (29.1\%) compared to the indigenous Dutch (5.9\%). Modifiable determinants included consumption of fatty fish, use of vitamin D supplements, area of uncovered skin and preference for sun (68). A similar study of non western pregnant women within midwife practices in the Hague measured the vitamin D concentrations of 358 women. Mean serum 25(OH)D concentrations were $15.2 \mathrm{nmol} / 1$ in the Turkish, $20.1 \mathrm{nmol} / 1$ in Moroccan and $52.7 \mathrm{nmol} / 1$ in the Dutch. Overall more than $80 \%$ of the Moroccan and Turkish immigrants were deficient $(25(\mathrm{OH}) \mathrm{D}<25 \mathrm{nmol} / \mathrm{l})$ compared to $6 \%$ of the Dutch with $22 \%$ of the Turkish women below detection point (69).

It can be concluded that vitamin D deficiency is common within Europe, specific at risk groups include non-western immigrants and the institutionalized elderly. The role of latitude in vitamin D status is not completely clear and higher serum levels in some Scandinavian studies may be due to diet or a genetic adaptation.

\section{Middle East}

Vitamin D deficiency is very common in this area of the world despite high levels of sunshine and UV radiation throughout the year. Studies in both Turkey and Jordan showed a strong relationship with clothing which in part may explain the low serum levels of $25(\mathrm{OH}) \mathrm{D}$ seen in these parts. A study of 22 men and 124 women in Jordan found that overall $59.9 \%$ of participants had a serum $25(\mathrm{OH}) \mathrm{D}$ level $<30 \mathrm{nmol} / \mathrm{l}$. Serum $25(\mathrm{OH}) \mathrm{D}$ was highest in women wearing western clothing and levels decreased to be lowest in traditional women wearing hijab and completely veiled women wearing niqab. Only $4 \%$ of this study group had serum levels $>50 \mathrm{nmol} / \mathrm{l}$, these were seen exclusively in men and the women wearing western clothing (70). A similar finding was seen in Turkish women, who wore three different dress types, serum $25(\mathrm{OH}) \mathrm{D}$ levels averaged $56 \mathrm{nmol} / 1$ in the western dressed group, $31.9 \mathrm{nmol} / 1$ in the second group wearing a hijab with uncovered face and hands, and only $9 \mathrm{nmol} / 1$ in the completed covered group suggesting that these women need supplementation due to lack of sunlight exposure (71). In a cross sectional study of 834 men living in the Jeddah region of Saudi Arabia, $87.8 \%$ had a serum $25(\mathrm{OH}) \mathrm{D}$ level $<50 \mathrm{nmol} / \mathrm{l}$, with an overall mean 29nmol/1 (72). A similar study of 1172 Saudi Arabian women from Jeddah found $80 \%$ had serum $25(\mathrm{OH}) \mathrm{D}$ levels $<50 \mathrm{nmol} / 1$ and about $10 \%$ were severely deficient with levels $<12.5 \mathrm{nmol} / 1$. There was no significant difference in the serum levels seen between fully veiled women and those who exposed their face and hands. The main risk factors for vitamin D deficiency were obesity, poor sun exposure, inadequate vitamin D supplementation, high waist to hip ratio and age (73).

Studies in children show a varying incidence of vitamin $\mathrm{D}$ deficiency. In a recent study of 440 children aged 0-16 years attending a paediatric clinic in Ankara Turkey, $40 \%$ of the children had 25(OH)D levels $<50 \mathrm{nmol} / 1$, of which 110 had levels $<37.5 \mathrm{nmol} / 1$. Children with deficiency were significantly older than those with normal levels (mean age 10.3 vs 5.6 years) (74). These results are probably related to the introduction of vitamin D supplementation to all newborns since 2005 throughout infancy at no financial cost. In a Saudi Arabian study of 510 children aged 4-15 years, vitamin D deficiency was highly prevalent. The mean concentration of $25(\mathrm{OH}) \mathrm{D}$ was $32.6 \mathrm{nmol} / \mathrm{l}$, only $13.7 \%$ had a level $>50 \mathrm{nmol} / 1$ and $27.5 \%$ had severe deficiency $(25(\mathrm{OH}) \mathrm{D}$ $<17.5 \mathrm{nmol} / \mathrm{l})$. Within this study population, the Saudis and Yemenis had a higher incidence of deficiency than 
the Egyptians and other nationalities (75).

\section{Africa}

Whilst there is a plethora of vitamin D data from elsewhere in the world, the number of studies originating from Africa is limited. However, those that have been completed show much higher baseline levels of serum $25(\mathrm{OH}) \mathrm{D}$ compared to the rest of the world although there is significant variation within the continent (31). In a study of 113 Gambian women aged $45-80$ years, the mean 25(OH)D level was $91.2 \mathrm{nmol} / 1$ and there was no association with age(76). In Cameroon, a study found that in 152 men and women over 60 years the mean $25(\mathrm{OH}) \mathrm{D}$ concentration was $52.7 \mathrm{nmol} / 1$ (77). A study assessing vitamin $\mathrm{D}$ status in the indigenous populations of Tanzania showed that the mean $25(\mathrm{OH}) \mathrm{D}$ was $106.8 \mathrm{nmol} / 1$ in non-pregnant women and $138.5 \mathrm{nmol} / 1$ in pregnant women. None of the subjects had levels below $25 \mathrm{nmol} / 1$. Women of Maasai and Hadzabe origin had higher 25(OH)D compared to women of Sengerema origin who cover all but their lower arms and faces (78). Thus, sunlight exposure rather than dietary intake appeared to be the principal determinant. There was a linear relationship between maternal and infant $25(\mathrm{OH}) \mathrm{D}$ (24). In a study of 200 black South Africans $>65$ years the mean serum $25(\mathrm{OH}) \mathrm{D}$ was $37 \mathrm{nmol} / 1$ whilst $17 \%$ had a level $<25 \mathrm{nmol} / 1$. Vitamin D levels appear to be slightly lower in North African countries. Investigators in Morocco studied 415 women aged $24-77$ years. The mean serum $25(\mathrm{OH}) \mathrm{D}$ was $45.9 \mathrm{nmol} / 1$ and $4 \%$ had a serum levels of $<10 \mathrm{nmol} / 1$. Veiling, age and a lack of sun exposure all contributed to an increase risk of insufficiency (79). Lower serum 25(OH)D levels were seen in veiled women in Tunisia compared to the non veiled women ( $35.7 \mathrm{vs} 42.5)$. In this population overall, $47.6 \%$ of women had a serum $25(\mathrm{OH}) \mathrm{D}<37.5 \mathrm{nmol} / 1$. The incidence of vitamin D deficiency increased with age (80).

\section{Asia}

It has previously been noted that Asian immigrants to higher latitude countries have a high incidence of vitamin $\mathrm{D}$ deficiency. It was thought that this was in part due to their skin not being adapted to cope with low levels of UV radiation. However, studies across different parts of Asia show a widespread prevalence of vitamin D insufficiency within both sexes and all age groups.

In India low serum levels of $25(\mathrm{OH}) \mathrm{D}$ are commonly seen. A study of 92 staff in an urban North Indian hospital found the mean serum 25(OH)D levels was $30 \mathrm{nmol} / 1$ and 19 of these subjects had serum levels $<12.5 \mathrm{nmol} / 1$ (81). In healthy pregnant women in Delhi the mean serum 25(OH)D was $23.2 \mathrm{nmol} / 1$. Serum levels of $25(\mathrm{OH}) \mathrm{D}<50 \mathrm{nmol} / 1$ were observed in $96.3 \%$ of the subjects (82). In healthy school children aged 6-18 years the mean serum $25(\mathrm{OH}) \mathrm{D}$ level was $31.9 \mathrm{nmol} / 1$ with $29.9 \%$ having a level $<22.4 \mathrm{nmol} / 1$. Lower serum levels were seen in children of higher socioeconomic class probably reflecting the increased BMI in this group (83). A study from northern Indian found low serum $25(\mathrm{OH}) \mathrm{D}(<55 \mathrm{nmol} / \mathrm{l})$ to be equally prevalent in rural (84.3)and urban(83.6)pregnant subjects, the mean level in his population was $34.9 \mathrm{nmol} / 1$ (84). Some studies however found urban subjects more likely to be deficient $(83,85)$. Air pollution may play a role, in a study from Delhi infants aged 9-24 months had significantly lower serum $25(\mathrm{OH}) \mathrm{D}$ in areas of high atmospheric pollution compared to infants from ales polluted part of the study (mean serum $25(\mathrm{OH}) \mathrm{D} 30.9 \mathrm{nmol} / 1$ vs $67.6 \mathrm{nmol} / \mathrm{l}$ ). Haze scores were lower in the polluted area indicating less solar UVB reaching the ground (86).

In Bangladesh serum 25(OH)D $<37.7 \mathrm{nmol} / 1$ was seen in $50 \%$ of those in low income groups (median $36.7 \mathrm{nmol} / 1)$ compared to $38 \%$ of high income groups (median $(43.5 \mathrm{nmol} / \mathrm{L})$. Prevalence of low 25(OH)D increased in lactating women (87). Vitamin D insufficiency $(<40 \mathrm{nmol} / \mathrm{l})$ was common $(80 \%)$ regardless of age, lifestyle and clothing in study from Dhaka (88). Similar data is seen in Pakistan where in a study of healthy breastfed infants and their mothers vitamin $\mathrm{D}$ deficiency $(25(\mathrm{OH}) \mathrm{D}<25 \mathrm{nmol} / \mathrm{L})$ was found in $55 \%$ of infants and $45 \%$ of mothers (89).

Vitamin D status in South East Asia is generally better. In a cross sectional study from Vietnam the mean $25(\mathrm{OH}) \mathrm{D}$ level was $91.8 \mathrm{nmol} / 1 \mathrm{in}$ men and $75.1 \mathrm{nmol} / 1 \mathrm{in}$ women (90). Across Thailand 2641 adults aged 15-98 years were selected from the Thai 4th National Health Examination Survey (2008-9) cohort. Subjects residing in Bangkok, had lower mean 25(OH)D levels than other parts of the country (Bangkok $64.8 \mathrm{nmol} / 1$, central $79.5 \mathrm{nmol} / 1$, northern $81.7 \mathrm{nmol} / 1$, north-eastern $82.2 \mathrm{nmol} / 1$ and southern regions $78.3 \mathrm{nmol} / \mathrm{l}$ ) (91). Within each region subjects living in the more urban areas had lower circulating 25(OH)D (91), this may reflect less time spent outdoors or atmospheric pollution. In Malaysia, a country with similar latitude, levels of $25(\mathrm{OH}) \mathrm{D}$ were significantly lower in the Malay women $(44.4 \mathrm{nmol} / \mathrm{L})$ compared to the Chinese women $(68.8 \mathrm{nmol} / \mathrm{L}) .71 \%$ of the Malay women had levels in the insufficient range $(25-50 \mathrm{nmol} / \mathrm{l})$ compared to $11 \%$ of the Chinese women (92). Malay women commonly wear traditional dress with only face and hands exposed. They have less sun exposure compared to the Chinese population.

Vitamin D insufficiency is highly prevalent in China and Mongolia where rickets is still seen commonly (93). A study in Linxian, a semi-arid mountainous area in central China, showed a mean $25(\mathrm{OH}) \mathrm{D}$ of $31.7 \mathrm{nmol}$ and $25 \%$ of the population had a serum level $<19.5 \mathrm{nmol} / 1$ (94). In a study of 301 healthy adolescent girls from Beijing, 57.8\% had vitamin D insufficiency (serum 
25(OH)D <50nmol/1), whilst $31.2 \%$ had levels $<25 \mathrm{nmol} / 1$. Adequate vitamin D status was associated with higher bone mass and higher grip strength in these adolescents (95). In Mongolia, a study of children aged 636 months found $61 \%$ of then to be deficient $(25(\mathrm{OH}) \mathrm{D}$ $<25 \mathrm{nmol} / \mathrm{l})(96)$.

Vitamin D status in Japan is relatively better than other regions of Asia, this thought to be due to high levels of fish consumption (97). In a cross sectional study of the elderly (65-92 years) in Japan mean serum 25(OH)D levels were significantly lower in the women compared to men $(60.4 \mathrm{nmol} / 1$ vs. $71.1 \mathrm{nmol} / 1)$ serum levels decreased with age in females but not the male population. Only $5 \%$ of men had levels in the insufficient range $(<50 \mathrm{nml} / 1)$ this compared to $17.7 \%$ in women (98).

\section{North America}

In the USA vitamin D status has been assessed using data from the National Health and Nutrition Examination Surveys (NHANES) which is a nationally representative, non-institutionalized sample of the population within the United States. In the 2000-2004 survey a representative sample was collected each year to give a total of 20,289 participants across all ages and ethnic groups (99). Mean levels of $25(\mathrm{OH}) \mathrm{D}$ were highest in the youngest group (children aged 1-5 years mean $76.4 \mathrm{nmol} / 1$ ) then fell in each subsequent age category $(6-11$ years, $70 \mathrm{nmol} / 1$; $12-$ 19 years, $63.9 \mathrm{nmol} / 1 ; 20-49,62 \mathrm{nmol} / 1 ; 50-60,59.2 \mathrm{nmol} / 1$ and $>70,57.5 \mathrm{nmol} / 1)$. Serum levels $<37.5 \mathrm{nmol} / 1$ were present in only $3 \%$ of those aged 1-5 years and $19 \%$ of adults aged 20-49 years. Overall mean levels were slightly higher in men than women $(62.9 \mathrm{nmol} / 1 \mathrm{vs}$. $61.5 \mathrm{nmol} / 1)$. Non-Hispanic whites had the highest mean serum levels $(66.9 \mathrm{nmol} / 1)$ followed by non Hispanic blacks (53.9nmol/1) and Mexican Americans $(40.1 \mathrm{nmol} / 1)$. Serum levels were also higher in samples taken between the months of April-October. Compared to the previous NHANES survey in 1988-1994 age adjusted means were lower in men by between $5-9 \mathrm{nmol} / 1$. This can in part be attributed to BMI, milk intake (which is the US is fortified with $400 \mathrm{IU}$ per quart) and sun protection.

A nationally representative survey from Canada (Canadian Health Measures survey) collected data on 5306 individuals aged 6-79 years between 2007 and 2009. The mean concentration of $25(\mathrm{OH}) \mathrm{D}$ in this population was $67.7 \mathrm{nmol} / 1$. Mean concentrations were lowest among men aged $20-39$ years $(60.7 \mathrm{nmol} / 1)$ and highest in boys aged $6-11$ years $(76.8 \mathrm{nmol} / 1)$. An estimated $4.1 \%$ of the population had $25(\mathrm{OH}) \mathrm{D}$ levels $<25 \mathrm{nmol} / 1$, and just over $10 \%$ had levels $<37.5 \mathrm{nmol} / 1$. White racial background and frequent milk consumption were associated with higher concentrations (100). Over a period of 10 years the Canadian Multicentre Osteoporosis study, which analysed samples of 1896 women and 829 men, showed that serum $25(\mathrm{OH}) \mathrm{D}$ increased by $9.3 \mathrm{nmol} / 1$ in women and by $3.5 \mathrm{nmol} / 1$ in men. The percentage of participants with $25(\mathrm{OH}) \mathrm{D}$ levels $<50 \mathrm{nmol} / \mathrm{L}$ was $29.7 \%$ at baseline and $19.8 \%$ at year 10 follow-up (101). This was in part due to increased use of supplements.

\section{Latin America}

Despite the large population of this area, only a few studies have assessed vitamin D status in the region. A multinational study of vitamin D status assessed individuals in Mexico, Brazil and Chile. Mean levels across the area were $73.8 \mathrm{nmol} / 1$. In the individual countries mean serum levels were $65.4 \mathrm{nmol} /$ in Mexico, 81.3 in Brazil and $75.4 \mathrm{nmol} / 1$ in Chile. The levels of vitamin D deficiency $(<22.5 \mathrm{nmol} / 1)$ were $1.3,0.7$ and $0 \%$ respectively, and insufficiency $(<50 \mathrm{nmol} / 1) 29.5,15.2$ and $19.1 \%$ respectively (102). A study in Argentina assessed the effect of latitude on vitamin D status. They found those living in the South had the lowest mean 25(OH)D levels $(35.4 \mathrm{nmol} / 1)$ compared to the mid region $(44.7 \mathrm{nmol} / 1)$ and North $(51.7 \mathrm{nmol} / 1)$ of the country (103).

\section{Oceania}

Vitamin D deficiency is seen in a number of at risk groups within Australia. A study of 1280 older men and women in residential care in Sydney found that the percentage of residents with vitamin $\mathrm{D}$ deficiency using cut off values of $25(\mathrm{OH}) \mathrm{D}$ at 30,50 and $75 \mathrm{nmol} / 1$ were $61.6 \%, 88.2 \%$ and $98.4 \%$ respectively (104). A study investigating at risk groups in the Sydney metropolitan area showed that serum $25(\mathrm{OH}) \mathrm{D}$ levels in the elderly population were higher in those living at home (44nmol/L) compared to individuals living in a hostel $(36 \mathrm{nmol} / 1)$ or nursing home $(33 \mathrm{nmol} / 1)$. Elderly participants of middle Eastern origin had the lowest mean level $(21 \mathrm{nmol} / 1)$ with $58 \%$ of this group having levels $<25 \mathrm{nmol} / 1$ (105). Other factors associated with vitamin $\mathrm{D}$ deficiency were mobility and sun exposure in people living in assisted care facilities, and low dietary vitamin $\mathrm{D}$ and calcium intake, reduced exercise and high BMI in the immigrant groups (51). A study from Tasmania found the mean serum $25(\mathrm{OH}) \mathrm{D}$ was $52.8 \mathrm{nmol} / \mathrm{l}$, with $56 \%$ of women in this cohort having a serum level $<50 \mathrm{nmol} / 1$ (106).

A national study of 3008 participants over 15 years (National nutritional study) in New Zealand showed that the mean level of $25(\mathrm{OH}) \mathrm{D}$ was $50 \mathrm{nmol} / 1$ with levels marginally lower in women $(48 \mathrm{nmol} / 1)$. Pacific women had the lowest levels $(34 \mathrm{nmol} / 1)$. Women living on the South Island had a lower serum level compared to the North Island (43 vs $49 \mathrm{nmol} / 1$ ). The proportion of adults described as deficient $(<17.5 \mathrm{nmol} / 1)$ ranged from $0 \%$ in men aged 19-24 years to $10 \%$ in pacific women (107). In the National Children's Survey, a national sample of children aged 5-14 years, mean $25(\mathrm{OH}) \mathrm{D}$ levels were 
43nmol/1 in Maori, 36nmol/1 in Pacific, and 53 in those of European decent (108). The prevalence of deficiency $(<17.5 \mathrm{nmol} / 1)$ was 5,8 and $3 \%$ respectively, and insufficiency $(<37.7 \mathrm{nmol} / 1)$ was 41,59 and $25 \%$ respectively. Lower levels were seen in girls and those with higher fat mass (108).

\section{Conclusion}

Vitamin D status has several important roles in bone and muscle health. Levels are determined by a combination of factors which influence synthesis in the skin, such as latitude and skin pigmentation, and dietary intake, such as food fortification and use of supplements. Level of adiposity may affect bioavailability, and demographic, genetic and disease factors can also play a role. It is clearly important to aim for a universal definition of what constitutes vitamin $\mathrm{D}$ deficiency to allow better comparability of studies. This will require collaboration and agreement across continents.

Regardless of the definition of vitamin D insufficiency it is apparent that sub optimal levels of $25(\mathrm{OH}) \mathrm{D}$ are a global problem with very few areas spared. Severe deficiency seems to be most common in the Middle East and South Asia. The high prevalence of rickets in these areas is of particular concern. Hypovitaminosis D is also particularly prevalent in immigrant populations to areas with less UV radiation. There are several areas, for example in Africa and Asia, where data are still not available on the prevalence of vitamin D deficiency. Future studies should focus on filling these knowledge gaps to provide a fuller picture of the global burden of this condition.

In terms of interventions, in regions such as Scandinavia, dietary supplements appear to have been effective in reducing the prevalence of deficiency. Furthermore, the food fortification used in North America has successfully increased the mean serum levels in the population. Both could be considered elsewhere in higher risk countries.

Conflicts of interest: Professor Cooper has received consultancy fees/honoraria from Servier; Eli Lilly; Merck; Amgen; Alliance; Novartis; Medtronic; GSK; Roche.

\section{References}

1. Heaney RP, Dowell MS, Hale CA, Bendich A. Calcium absorption varies within the reference range for serum 25-hydroxyvitamin D. J Am Coll Nutr 2003;22:142-146.

2. Steingrimsdottir L, Gunnarsson O, Indridason OS, Franzson L, Sigurdsson G. Relationship between serum parathyroid hormone levels, vitamin D sufficiency, and calcium intake. JAMA 2005;294:2336-2341.

3. Ooms ME, Roos JC, Bezemer PD, van der Vijgh WJ, Bouter LM, Lips P. Prevention of bone loss by vitamin D supplementation in elderly women: a randomized doubleblind trial. J Clin Endocrinol Metab 1995;80:1052-1058.

4. Dawson-Hughes B, Dallal GE, Krall EA, Harris S, Sokoll LJ, Falconer G. Effect of vitamin D supplementation on wintertime and overall bone loss in healthy postmenopausal women. Ann Intern Med 1991;115:505-512.

5. Reid IR, Bolland MJ, Grey A. Effects of vitamin D supplements on bone mineral density: a systematic review and meta-analysis. Lancet, 2013

6. Bischoff-Ferrari HA, Kiel DP, Dawson-Hughes B, Orav JE, Li R, Spiegelman D, Dietrich T, Willett WC. Dietary calcium and serum 25-hydroxyvitamin D status in relation to BMD among U.S. adults. J Bone Miner Res 2009;24:935-942.
7. Avenell A, Gillespie WJ, Gillespie LD, O'Connell D. Vitamin D and vitamin D analogues for preventing fractures associated with involutional and post-menopausal osteoporosis. Cochrane Database Syst Rev 2009; CD000227.

8. Patient level pooled analysis of 68500 patients from seven major vitamin D fracture trials in US and Europe. BMJ 2010;340:b5463-

9. Venning G. Recent developments in vitamin D deficiency and muscle weakness among elderly people. BMJ 2005;330:524-526.

10. Pfeifer M, Begerow B, Minne HW. Vitamin D and muscle function. Osteoporos Int 2002:13:187-194.

11. Morelli S, de Boland AR, Boland RL. Generation of inositol phosphates, diacylglycerol and calcium fluxes in myoblasts treated with 1,25-dihydroxyvitamin D3. Biochem J1993; 289 ( Pt 3):675-679.

12. de Boland AR and Boland RL. 1,25-Dihydroxyvitamin D-3 induces arachidonate mobilization in embryonic chick myoblasts. Biochim Biophys Acta 1993;1179:98104.

13. Glerup H, Mikkelsen K, Poulsen L, Hass E, Overbeck S, Andersen H, Charles P, Eriksen EF. Hypovitaminosis D myopathy without biochemical signs of osteomalacic bone involvement. Calcif Tissue Int 2000;66:419-424.

14. Skaria J, Katiyar BC, Srivastava TP, Dube B. Myopathy and neuropathy associated with osteomalacia. Acta Neurol Scand 1975;51:37-58.

15. Annweiler C, Schott AM, Berrut G, Fantino B, Beauchet O. Vitamin D-related changes in physical performance: a systematic review. J Nutr Health Aging 2009;13:893-898.

16. Annweiler C, Schott-Petelaz AM, Berrut G, Kressig RW, Bridenbaugh S, Herrmann FR, Beauchet O. Vitamin D deficiency-related quadriceps weakness: results of the Epidemiologie De l'Osteoporose cohort. J Am Geriatr Soc 2009;57:368-369.

17. Bischoff HA, Stahelin HB, Urscheler N, Ehrsam R, Vonthein R, Perrig-Chiello P, Tyndall A, Theiler R. Muscle strength in the elderly: its relation to vitamin D metabolites. Arch Phys Med Rehabil 1999;80:54-58.

18. Annweiler C, Beauchet O, Berrut G, Fantino B, Bonnefoy M, Herrmann FR, Schott $\mathrm{AM}$. Is there an association between serum 25-hydroxyvitamin D concentration and muscle strength among older women? Results from baseline assessment of the EPIDOS study. J Nutr Health Aging 2009;13:90-95.

19. Gorham ED, Garland CF, Garland FC, Grant WB, Mohr SB, Lipkin M, Newmark HL, Giovannucci E, Wei M, Holick MF. Optimal vitamin D status for colorectal cancer prevention: a quantitative meta analysis. Am J Prev Med 2007;32:210-216.

20. Pittas AG, Harris SS, Stark PC, Dawson-Hughes B. The effects of calcium and vitamin D supplementation on blood glucose and markers of inflammation in nondiabetic adults. Diabetes Care 2007;30:980-986.

21. Urashima M, Segawa T, Okazaki M, Kurihara M, Wada Y, Ida H. Randomized trial of vitamin D supplementation to prevent seasonal influenza A in schoolchildren. Am J Clin Nutr 2010:91:1255-1260.

22. Holick MF. Vitamin D deficiency. N Engl J Med 2007;357:266-281.

23. Verhoeven V, Vanpuyenbroeck K, Lopez-Hartmann M, Wens J, Remmen R. Walk on the sunny side of life--epidemiology of hypovitaminosis D and mental health in elderly nursing home residents. J Nutr Health Aging 2012;16:417-420.

24. Boersma D, Demontiero O, Mohtasham AZ, Hassan S, Suarez H, Geisinger D, Suriyaarachchi P, Sharma A, Duque G. Vitamin D status in relation to postural stability in the elderly. J Nutr Health Aging 2012;16:270-275

25. Waldron JL, Ashby HL, Cornes MP, Bechervaise J, Razavi C, Thomas OL, Chugh S, Deshpande S, Ford C, Gama R. Vitamin D: a negative acute phase reactant. J Clin Pathol 2013;66:620-622.

26. Reid D, Toole BJ, Knox S, Talwar D, Harten J, O'Reilly DS, Blackwell S, Kinsella J, McMillan DC, Wallace AM. The relation between acute changes in the systemic inflammatory response and plasma 25-hydroxyvitamin D concentrations after elective knee arthroplasty. Am J Clin Nutr 2011;93:1006-1011.

27. Rosen CJ, Adams JS, Bikle DD, Black DM, Demay MB, Manson JE, Murad MH, Kovacs CS. The nonskeletal effects of vitamin D: an Endocrine Society scientific statement. Endocr Rev 2012;33:456-492.

28. Muszkat P, Camargo MB, Griz LH, Lazaretti-Castro M. Evidence-based non-skeletal actions of vitamin D. Arq Bras Endocrinol Metabol 2010;54:110-117.

29. Holick MF. Vitamin D status: measurement, interpretation, and clinical application. Ann Epidemiol 19:73-78.

30. Lips P. Vitamin D deficiency and secondary hyperparathyroidism in the elderly: consequences for bone loss and fractures and therapeutic implications. Endocr Rev 2001;22:477-501.

31. van Schoor NM and Lips P. Worldwide vitamin D status. Best Pract Res Clin Endocrinol Metab 2011;25:671-680.

32. Priemel M, von DC, Klatte TO, Kessler S, Schlie J, Meier S, Proksch N, Pastor F, Netter C, Streichert T, Puschel K, Amling M. Bone mineralization defects and vitamin D deficiency: histomorphometric analysis of iliac crest bone biopsies and circulating 25-hydroxyvitamin D in 675 patients. J Bone Miner Res 2010;25:305312 .

33. Sai AJ, Walters RW, Fang X, Gallagher JC. Relationship between vitamin D, parathyroid hormone, and bone health. J Clin Endocrinol Metab 2011:96:E436-E446.

34. Mithal A, Wahl DA, Bonjour JP, Burckhardt P, Dawson-Hughes B, Eisman JA, ElHajj FG, Josse RG, Lips P, Morales-Torres J. Global vitamin D status and determinants of hypovitaminosis D. Osteoporos Int 2009;20:1807-1820.

35. Macdonald HM, Mavroeidi A, Fraser WD, Darling AL, Black AJ, Aucott L, O'Neill F, Hart K, Berry JL, Lanham-New SA, Reid DM. Sunlight and dietary contributions to the seasonal vitamin D status of cohorts of healthy postmenopausal women living 
at northerly latitudes: a major cause for concern? Osteoporos Int 2011;22:2461-2472. 36. Batieha A, Khader Y, Jaddou H, Hyassat D, Batieha Z, Khateeb M, Belbisi A, Ajlouni K. Vitamin D status in Jordan: dress style and gender discrepancies. Ann Nutr Metab 2011;58:10-18.

37. Gannage-Yared MH, Chemali R, Yaacoub N, Halaby G. Hypovitaminosis D in a sunny country: relation to lifestyle and bone markers. J Bone Miner Res 2000;15:1856-1862.

38. Matsuoka LY, Ide L, Wortsman J, MacLaughlin JA, Holick MF. Sunscreens suppress cutaneous vitamin D3 synthesis. J Clin Endocrinol Metab 1987;64:1165-1168.

39. Matsuoka LY, Wortsman J, Hanifan N, Holick MF. Chronic sunscreen use decreases circulating concentrations of 25-hydroxyvitamin D. A preliminary study. Arch Dermatol 1988;124:1802-1804.

40. Marks R, Foley PA, Jolley D, Knight KR, Harrison J, Thompson SC. The effect of regular sunscreen use on vitamin D levels in an Australian population. Results of a randomized controlled trial. Arch Dermatol 1995;131:415-421.

41. Garg S, Sabri D, Kanji J, Rakkar PS, Lee Y, Naidoo N, Svirskis D. Evaluation of vitamin D medicines and dietary supplements and the physicochemical analysis of selected formulations. J Nutr Health Aging 2013;17:158-161

42. Lips P. Vitamin D status and nutrition in Europe and Asia. J Steroid Biochem Mol Biol 2007; 103:620-625.

43. Calvo MS, Whiting SJ, Barton CN. Vitamin D fortification in the United States and Canada: current status and data needs. Am J Clin Nutr 2004;80:1710S-1716S.

44. Lagunova Z, Porojnicu AC, Lindberg F, Hexeberg S, Moan J (2009) The dependency of vitamin D status on body mass index, gender, age and season. Anticancer Res 2009;29:3713-3720.

45. Snijder MB, van Dam RM, Visser M, Deeg DJ, Dekker JM, Bouter LM, Seidell JC Lips P. Adiposity in relation to vitamin D status and parathyroid hormone levels: a population-based study in older men and women. J Clin Endocrinol Metab 2005;90:4119-4123.

46. Mawer EB, Backhouse J, Holman CA, Lumb GA, Stanbury SW. The distribution and storage of vitamin D and its metabolites in human tissues. Clin Sci 1972;43:413-431.

47. Wortsman J, Matsuoka LY, Chen TC, Lu Z, Holick MF. Decreased bioavailability of vitamin D in obesity. Am J Clin Nutr 2000;72:690-693.

48. Wang TJ, Zhang F, Richards JB, Kestenbaum B, van Meurs JB, Berry D, Kiel DP, Streeten EA, Ohlsson C, Koller DL, Peltonen L, Cooper JD, O'Reilly PF, Houston DK, Glazer NL, Vandenput L, Peacock M, Shi J, Rivadeneira F, McCarthy MI, Anneli P, de Boer IH, Mangino M, Kato B, Smyth DJ, Booth SL, Jacques PF, Burk GL, Goodarzi M, Cheung CL, Wolf M, Rice K, Goltzman D, Hidiroglou N, Ladouceur M, Wareham NJ, Hocking LJ, Hart D, Arden NK, Cooper C, Malik S, Fraser WD, Hartikainen AL, Zhai G, Macdonald HM, Forouhi NG, Loos RJ, Reid DM, Hakim A, Dennison E, Liu Y, Power C, Stevens HE, Jaana L, Vasan RS Soranzo N, Bojunga J, Psaty BM, Lorentzon M, Foroud T, Harris TB, Hofman A, Jansson JO, Cauley JA, Uitterlinden AG, Gibson Q, Jarvelin MR, Karasik D, Siscovick DS, Econs MJ, Kritchevsky SB, Florez JC, Todd JA, Dupuis J, Hypponen $\mathrm{E}$, Spector TD. Common genetic determinants of vitamin D insufficiency: a genomewide association study. Lancet 2010;376:180-188.

49. Arabi A, Baddoura R, El-Rassi R, El-Hajj FG. Age but not gender modulates the relationship between PTH and vitamin D. Bone 2010;47:408-412.

50. Hagenau T, Vest R, Gissel TN, Poulsen CS, Erlandsen M, Mosekilde L, Vestergaar P. Global vitamin D levels in relation to age, gender, skin pigmentation and latitude: an ecologic meta-regression analysis. Osteoporos Int 2009;20:133-140.

51. Gharaibeh MA and Stoecker BJ. Assessment of serum 25(OH)D concentration in women of childbearing age and their preschool children in Northern Jordan during summer. Eur J Clin Nutr 2009;63:1320-1326.

52. Ginde AA, Liu MC, Camargo CA, Jr. Demographic differences and trends of vitamin D insufficiency in the US population, 1988-2004. Arch Intern Med 2009;169:626632.

53. Theiler R, Stahelin HB, Tyndall A, Binder K, Somorjai G, Bischoff HA. Calcidiol, calcitriol and parathyroid hormone serum concentrations in institutionalized and ambulatory elderly in Switzerland. Int J Vitam Nutr Res 1999;69:96-105.

54. Dijkstra SH, van BA, Janssen JW, de Vleeschouwer LH, Huysman WA, van den Akker EL. High prevalence of vitamin D deficiency in newborn infants of high-risk mothers. Arch Dis Child 2007:92:750-753.

55. Institute of Medicine (US) Committee to Review Dietary Reference Intakes for Vitamin D and Calcium. Dietary Reference Intakes for Calcium and Vitamin D, 2011.

56. van der Wielen RP, Lowik MR, van den Berg H, de Groot LC, Haller J, Moreiras O, van Staveren WA. Serum vitamin D concentrations among elderly people in Europe. Lancet 1995;346:207-210

57. Lips P, Duong T, Oleksik A, Black D, Cummings S, Cox D, Nickelsen T. A global study of vitamin D status and parathyroid function in postmenopausal women with osteoporosis: baseline data from the multiple outcomes of raloxifene evaluation clinical trial. J Clin Endocrinol Metab 2001;86:1212-1221.

58. Melhus H, Snellman G, Gedeborg R, Byberg L, Berglund L, Mallmin H, Hellman P, Blomhoff R, Hagstrom E, Arnlov J, Michaelsson K. Plasma 25-hydroxyvitamin D levels and fracture risk in a community-based cohort of elderly men in Sweden. J Clin Endocrinol Metab 2010;95:2637-2645.

59. Chapuy MC, Preziosi P, Maamer M, Arnaud S, Galan P, Hercberg S, Meunier PJ Prevalence of vitamin D insufficiency in an adult normal population. Osteoporos Int 1997;7:439-443

60. Semba RD, Houston DK, Bandinelli S, Sun K, Cherubini A, Cappola AR, Guralnik JM, Ferrucci L. Relationship of 25-hydroxyvitamin D with all-cause and cardiovascular disease mortality in older community-dwelling adults. Eur J Clin Nutr 2010;64:203-209.

61. Burnand B, Sloutskis D, Gianoli F, Cornuz J, Rickenbach M, Paccaud F, Burckhard P. Serum 25-hydroxyvitamin D: distribution and determinants in the Swiss population. Am J Clin Nutr 1992;56:537-542.

62. Pilz S, Dobnig H, Tomaschitz A, Kienreich K, Meinitzer A, Friedl C, Wagner D, Piswanger-Solkner C, Marz W, Fahrleitner-Pammer A. Low 25-hydroxyvitamin D is associated with increased mortality in female nursing home residents. J Clin Endocrinol Metab 2012;97:E653-E657.

63. Krieg MA, Cornuz J, Jacquet AF, Thiebaud D, Burckhardt P. Influence of anthropometric parameters and biochemical markers of bone metabolism on quantitative ultrasound of bone in the institutionalized elderly. Osteoporos Int 1998;8:115-120

64. Tolppanen AM, Fraser A, Fraser WD, Lawlor DA. Risk factors for variation in 25hydroxyvitamin $\mathrm{D}(3)$ and $\mathrm{D}(2)$ concentrations and vitamin $\mathrm{D}$ deficiency in children. J Clin Endocrinol Metab 2012;97:1202-1210.

65. Davies JH, Reed JM, Blake E, Priesemann M, Jackson AA, Clarke NM. Epidemiology of vitamin D deficiency in children presenting to a pediatric orthopaedic service in the UK. J Pediatr Orthop 2011;31:798-802.

66. Das G, Crocombe S, McGrath M, Berry JL, Mughal MZ. Hypovitaminosis D among healthy adolescent girls attending an inner city school. Arch Dis Child 2006;91:569572 .

67. Serhan E, Newton P, Ali HA, Walford S, Singh BM. Prevalence of hypovitaminosis $\mathrm{D}$ in Indo-Asian patients attending a rheumatology clinic. Bone 1999;25:609-611. 68. van der Meer IM, Boeke AJ, Lips P, Grootjans-Geerts I, Wuister JD, Deville WL, Wielders JP, Bouter LM, Middelkoop BJ. Fatty fish and supplements are the greatest modifiable contributors to the serum 25 -hydroxyvitamin $\mathrm{D}$ concentration in a multiethnic population. Clin Endocrinol (Oxf) 2008;68:466-472.

69. van der Meer IM, Karamali NS, Boeke AJ, Lips P, Middelkoop BJ, Verhoeven I, Wuister JD. High prevalence of vitamin D deficiency in pregnant non-Western women in The Hague, Netherlands. Am J Clin Nutr 2006;84:350-353.

70. Mishal AA. Effects of different dress styles on vitamin D levels in healthy young Jordanian women. Osteoporos Int 2001;12:931-935.

71. Alagol F, Shihadeh Y, Boztepe H, Tanakol R, Yarman S, Azizlerli H, Sandalci O. Sunlight exposure and vitamin D deficiency in Turkish women. J Endocrinol Invest 2000;23:173-177.

72. Ardawi MS, Sibiany AM, Bakhsh TM, Qari MH, Maimani AA. High prevalence of vitamin D deficiency among healthy Saudi Arabian men: relationship to bone mineral density, parathyroid hormone, bone turnover markers, and lifestyle factors. Osteoporos Int 2012;23:675-686.

73. Ardawi MS, Qari MH, Rouzi AA, Maimani AA, Raddadi RM. Vitamin D status in relation to obesity, bone mineral density, bone turnover markers and vitamin D receptor genotypes in healthy Saudi pre- and postmenopausal women. Osteoporos Int 2011;22:463-475.

74. Andiran N, Celik N, Akca H, Dogan G. Vitamin D deficiency in children and adolescents. J Clin Res Pediatr Endocrinol 2012;4:25-29.

75. Mansour MM and Alhadidi KM. Vitamin D deficiency in children living in Jeddah, Saudi Arabia. Indian J Endocrinol Metab 2012;16:263-269.

76. Aspray TJ, Yan L, Prentice A. Parathyroid hormone and rates of bone formation are raised in perimenopausal rural Gambian women. Bone 2005;36:710-720.

77. Njemini R, Meyers I, Demanet C, Smitz J, Sosso M, Mets T. The prevalence of autoantibodies in an elderly sub-Saharan African population. Clin Exp Immunol 2002;127:99-106.

78. Luxwolda MF, Kuipers RS, Kema IP, van d, V, Dijck-Brouwer DA, Muskiet FA Vitamin D status indicators in indigenous populations in East Africa. Eur J Nutr, 2012

79. Allali F, El AS, Khazani H, Benyahia B, Saoud B, El KS, Bahiri R, Abouqal R, Hajjaj-Hassouni N. High prevalence of hypovitaminosis D in Morocco: relationship to lifestyle, physical performance, bone markers, and bone mineral density. Semin Arthritis Rheum 2009;38:444-451.

80. Meddeb N, Sahli H, Chahed M, Abdelmoula J, Feki M, Salah H, Frini S, Kaabach N, Belkahia C, Mbazaa R, Zouari B, Sellami S. Vitamin D deficiency in Tunisia Osteoporos Int 2005;16:180-183.

81. Arya V, Bhambri R, Godbole MM, Mithal A. Vitamin D status and its relationship with bone mineral density in healthy Asian Indians. Osteoporos Int 2004;15:56-61.

82. Marwaha RK, Tandon N, Chopra S, Agarwal N, Garg MK, Sharma B, Kanwar RS Bhadra K, Singh S, Mani K, Puri S. Vitamin D status in pregnant Indian women across trimesters and different seasons and its correlation with neonatal serum 25hydroxyvitamin D levels. Br J Nutr 2011;106:1383-1389.

83. Puri S, Marwaha RK, Agarwal N, Tandon N, Agarwal R, Grewal K, Reddy DH, Singh S. Vitamin D status of apparently healthy schoolgirls from two different socioeconomic strata in Delhi: relation to nutrition and lifestyle. Br J Nutr 2008:99:876-882

84. Sachan A, Gupta R, Das V, Agarwal A, Awasthi PK, Bhatia V. High prevalence of vitamin $\mathrm{D}$ deficiency among pregnant women and their newborns in northern India. Am J Clin Nutr 2005;81:1060-1064.

85. Harinarayan CV, Ramalakshmi T, Venkataprasad U. High prevalence of low dietary calcium and low vitamin D status in healthy south Indians. Asia Pac J Clin Nutr 2004;13:359-364.

86. Agarwal KS, Mughal MZ, Upadhyay P, Berry JL, Mawer EB, Puliyel JM. The impact of atmospheric pollution on vitamin D status of infants and toddlers in Delhi, India. Arch Dis Child 2002;87:111-113. 
87. Islam MZ, Lamberg-Allardt C, Karkkainen M, Outila T, Salamatullah Q, Shamim AA. Vitamin D deficiency: a concern in premenopausal Bangladeshi women of two socio-economic groups in rural and urban region. Eur J Clin Nutr 2002;56:51-56.

88. Islam MZ, Akhtaruzzaman M, Lamberg-Allardt C. Hypovitaminosis D is common in both veiled and nonveiled Bangladeshi women. Asia Pac J Clin Nutr 2006;15:81-87.

89. Atiq M, Suria A, Nizami SQ, Ahmed I. Vitamin D status of breastfed Pakistani infants. Acta Paediatr 1998:87:737-740.

90. Ho-Pham LT, Nguyen ND, Lai TQ, Eisman JA, Nguyen TV. Vitamin D status and parathyroid hormone in a urban population in Vietnam. Osteoporos Int 2011;22:241248.

91. Chailurkit LO, Aekplakorn W, Ongphiphadhanakul B. Regional variation and determinants of vitamin D status in sunshine-abundant Thailand. BMC Public Health 2011;11:853-

92. Rahman SA, Chee WS, Yassin Z, Chan SP. Vitamin D status among postmenopausal Malaysian women. Asia Pac J Clin Nutr 2004;13:255-260.

93. Fraser DR. Vitamin D-deficiency in Asia. J Steroid Biochem Mol Biol 2004;8990:491-495.

94. Chen W, Dawsey SM, Qiao YL, Mark SD, Dong ZW, Taylor PR, Zhao P, Abnet CC. Prospective study of serum 25(OH)-vitamin D concentration and risk of oesophageal and gastric cancers. Br J Cancer 2007;97:123-128.

95. Foo LH, Zhang Q, Zhu K, Ma G, Hu X, Greenfield H, Fraser DR. Low vitamin D status has an adverse influence on bone mass, bone turnover, and muscle strength in Chinese adolescent girls. J Nutr 2009;139:1002-1007.

96. Lander RL, Enkhjargal T, Batjargal J, Bailey KB, Diouf S, Green TJ, Skeaff CM, Gibson RS. Multiple micronutrient deficiencies persist during early childhood in Mongolia. Asia Pac J Clin Nutr 2008;17:429-440.

97. Ono Y, Suzuki A, Kotake M, Zhang X, Nishiwaki-Yasuda K, Ishiwata Y, Imamura S, Nagata M, Takamoto S, Itoh M. Seasonal changes of serum 25-hydroxyvitamin D and intact parathyroid hormone levels in a normal Japanese population. J Bone Miner Metab 2005;23:147-151.

98. Suzuki T, Kwon J, Kim H, Shimada H, Yoshida Y, Iwasa H, Yoshida H. Low serum 25-hydroxyvitamin D levels associated with falls among Japanese communitydwelling elderly. J Bone Miner Res 2008;23:1309-1317.

99. Looker AC, Pfeiffer CM, Lacher DA, Schleicher RL, Picciano MF, Yetley EA. Serum 25-hydroxyvitamin D status of the US population: 1988-1994 compared with
2000-2004. Am J Clin Nutr 2008;88:1519-1527.

100. Langlois K, Greene-Finestone L, Little J, Hidiroglou N, Whiting S. Vitamin D status of Canadians as measured in the 2007 to 2009 Canadian Health Measures Survey. Health Rep 2010;21:47-55.

101. Berger C, Greene-Finestone LS, Langsetmo L, Kreiger N, Joseph L, Kovacs CS, Richards JB, Hidiroglou N, Sarafin K, Davison KS, Adachi JD, Brown J, Hanley DA, Prior JC, Goltzman D. Temporal trends and determinants of longitudinal change in 25-hydroxyvitamin D and parathyroid hormone levels. J Bone Miner Res 2012;27:1381-1389.

102. Lips P, Hosking D, Lippuner K, Norquist JM, Wehren L, Maalouf G, Ragi-Eis S, Chandler J. The prevalence of vitamin D inadequacy amongst women with osteoporosis: an international epidemiological investigation. J Intern Med 2006;260:245-254

103. Oliveri B, Plantalech L, Bagur A, Wittich AC, Rovai G, Pusiol E, Lopez GJ, Ponce G, Nieva A, Chaperon A, Ladizesky M, Somoza J, Casco C, Zeni S, Parisi MS, Mautalen CA. High prevalence of vitamin D insufficiency in healthy elderly people living at home in Argentina. Eur J Clin Nutr 2004;58:337-342.

104. Chen JS, Sambrook PN, March L, Cameron ID, Cumming RG, Simpson JM, Seibel MJ. Hypovitaminosis D and parathyroid hormone response in the elderly: effects on bone turnover and mortality. Clin Endocrinol (Oxf) 2008;68:290-298.

105. Brock K, Wilkinson M, Cook R, Lee S, Bermingham M. Associations with Vitamin D deficiency in "at risk" Australians. J Steroid Biochem Mol Biol 2004;89-90:581588 .

106. Ding C, Cicuttini F, Parameswaran V, Burgess J, Quinn S, Jones G. Serum levels of vitamin D, sunlight exposure, and knee cartilage loss in older adults: the Tasmanian older adult cohort study. Arthritis Rheum 2009;60:1381-1389.

107. Rockell JE, Skeaff CM, Williams SM, Green TJ. Serum 25-hydroxyvitamin D concentrations of New Zealanders aged 15 years and older. Osteoporos Int 2006;17:1382-1389.

108. Rockell JE, Green TJ, Skeaff CM, Whiting SJ, Taylor RW, Williams SM, Parnell WR, Scragg R, Wilson N, Schaaf D, Fitzgerald ED, Wohlers MW. Season and ethnicity are determinants of serum 25-hydroxyvitamin D concentrations in New Zealand children aged 5-14 y. J Nutr 2005;135:2602-2608 